David Airey

University of Surrey, UK (Emeritus)

UDC 005.94:338.48

\title{
TOURISM EDUCATION: PAST, PRESENT AND FUTURE
}

\section{Introduction}

Tourism education, as we know it today, has a history going back about 50 years. There are examples of tourism being studied in higher education before this time, at the Universities of Rome in 1925, Vienna, 1936 and St Gallen and Berne 1941 (Medlik, 1965) but it was not until the middle of the 1960s that "tourism began to appear more generally in the academic repertoire of higher education" (Airey, Dredge, \& Gross, 2015 , p. 6). Since then, from very small beginnings, tourism has become established as a subject of teaching and research in universities and colleges across the world, with its distinctive literature, academic community and areas of research. This paper sets out to examine the background and development of this new subject area and in doing so it explores three main themes. The first deals with the growth and maturing of tourism in higher education. This then leads to a consideration of the current tensions and pressures on the subject, which in many ways raise questions about its survival as a separate area of study. And from this the possible futures of tourism are examined with the suggestion that it is very well suited as a subject of study for a post-industrial world. The paper draws on a range of sources and in particular makes use of evidence provided by research carried out by the author and colleagues over the past decade (Airey, 2008a, 2008b, 2015;
Airey, Tribe, Benckendorff, \& Xiao, 2015; Dredge, Airey, \& Gross, 2015).

\section{From Growth to Maturity}

The development of tourism in higher education was not accidental. Airey (2005) has identified three growth factors that lie behind the emergence of tourism after the mid-1960s. The first was the growth of tourism itself and its recognition, especially by governments, as an increasingly important economic activity. The second was the growth of higher education generally as the link between an educated workforce and economic development was increasingly recognised. Linked to this, the third factor was the creation of new universities. These, free from the traditions of the older universities, provided homes for new and often more vocational areas of study. With its potential to attract new students, tourism proved popular programme to include in the offerings of the new universities. The result was a huge increase in the numbers of programmes, students and subsequently the research and literature related to tourism. For example Airey et al. (2015) give examples of there being 20 tourism students in the UK and 1972 and 9,000 in 2011; in Australia following the introduction of the first programme in 1978 there were 61 in 2005; and from its first programme, also in 1978, in China, by 2010 there were 967 institutions offering tourism, 
recruiting over half a million students. At the same time the number of academic journals dealing with tourism increased from one in 1970 to at least 150 today.

This growth has led a number of authors to address the question as to whether tourism has matured as a subject (Airey, 2008a), or as one report put it (Council for National Academic Awards, 1993) whether tourism has "Come of Age". Pointing to the numbers of students, institutions and publications; to the general agreement about the curriculum; to the development of the research base and to the extension of methodological approaches and research techniques; to the so-called "cultural turn" (Aitchison, 2006) whereby tourism scholars were increasingly considering issues well beyond the vocational and economic; and with increasing selfcritical awareness, there were good grounds to reach a conclusion that tourism had taken its place alongside other subjects in the broader social sciences community. Against this, however, questions about the lack of a coherent theoretical framework, the extent to which tourism needs to draw upon other disciplines to provide explanations, the "hostile knowledge adoption environment" (Cooper, 2006, p. 47), the limited amount of threshold knowledge (Meyer \& Land, 2003) in tourism as well as the continuing debate about the balance between capabilities and knowledge suggest that, at least for some, tourism still has some way to go before it is fully mature.

\section{Survival in a Neo-Liberal World}

For much of the time during which the study of tourism was developing, the academy itself was coming under increasing pressure. In particular the political economic context was increasingly influenced by what is referred to as neo-liberalism which Harvey (2007, p. 22) describes as "the maximisation of entrepreneurial freedoms within an institutional framework characterised by private property rights, individual liberty, unencumbered markets and free trade". For institutions of higher education this has brought with it reductions in support from taxation and increasing reliance on students (and their parents) for the payment of fees, increasing marketization, with the introduction of privately owned schools and universities and increased scrutiny about performance. And at the same time there has been increasing internationalisation. These changes have brought with them an intensification and internationalisation of competition between institutions, especially for student recruitment and the greater awareness and importance of rankings and league tables of performance such that the two key drivers of the strategic direction of institutions have become income and reputation. In short, success is measured by the extent to which the activities of a university are judged to contribute to income and reputation.

With this background Airey et al. (2015), focusing on teaching, research and impact, explored the contribution of tourism to income and reputation of universities in three countries, Australia, China and the UK. The results of their study suggest some significant difficulties for tourism. As far as teaching is concerned tourism is in a reasonably strong position with student recruitment and hence income from student fees generally comparing well with other subject areas and the quality of the teaching being generally well regarded, with some exciting pedagogies and good student satisfaction. On the other hand the overall quality of research outputs and the amount and quality of research funding are not high and in terms of impact, as already noted, knowledge management is not well developed. With this sort of evaluation of contribution to income and research it is perhaps not surprising that a number of institutions have ceased to offer tourism. In others tourism has come under increasing pressure, particularly to increase 
the amount and quality of research and associated funding. For individual faculty members this has heightened the tension between time devoted to teaching and time devoted to research. Hence, during the past few years survival has become increasingly discussed in the context of tourism in many parts of the world.

\section{Tourism in a Post-Industrial World}

In his recent examination of tourism education, Airey (2015) suggests two directions that the subject area could take. The first is to respond to the metrics thrown up by a neo-liberal environment, relating to contributions to income and reputation, which, as noted above, present some difficulties for tourism. In many ways this sort of action is unavoidable. It is essential to ensure that those joining tourism programmes are adequately qualified; that inferior research does not continue; that research income is increased and that the tourism academy ensures that its messages are communicated to and where appropriate are taken up by the wider tourism world. All of these fall within the proper role of the academy, no matter what the subject. However these sorts of actions alone are not sufficient in a highly competitive world and they will inevitably raise the tension between research and teaching. They are also very inward looking reflecting Barnett's words that (2013, p. 60) the "the university's gaze has shrunk to a concern with its fortunes in the immediate world". The second direction is to emphasise what is special and particularly positive about tourism as a subject for study. It is here that advantage is found in distinguishing this field of study from others. Barnett's reflections on higher education provide a direction here. He comments (Barnett, 2004, p. 259):

"In an age of "super complexity" it is not knowledge and skills that are of most importance but "certain kinds of human qualities [including] carefulness, thoughtfulness, humility, criticality, receptiveness, resilience, knowledge and stillness."

With Austin (2012, p. 58) adding:

"the primary responsibility of those who teach within higher education institutions is to prepare students for an uncertain and changing world."

Taking these thoughts as a context, among the key characteristics of tourism as an area of study is that it is multi-sector, multi-disciplinary and multi-method and as Tribe (1997) has suggested it is not set within tight disciplinary boundaries. Rather, as Airey et al. (2015, p. 148) have suggested:

"it does lend itself well to drawing on a wide range of approaches and methods of research [that make] tourism well suited to provide the sort of educational experiences that will meet the challenges of a world of increasing complexity".

This point is taken up by Dredge et al. (2015, p. 547):

"it offers learning of the deep, intimate connections between knowledge and daily life and the capacity to develop critical, mindful and reflexive practice"

And Airey (2015, p. 13):

"In dealing with a current world issue that provides a vehicle for exploring so many different aspects of the challenges facing modern societies - economic, social, environmental, philosophical - and without being bound to particular approaches, tourism is extraordinarily well placed to provide education and research suited to the needs of the stewardship of a complex world." 


\section{Conclusion}

After 50 years of development in the academy, tourism has clearly come a long way. It has a certainly grown and matured and it has faced the challenges that are facing all subjects in the academy. The big question now is how it survives in a rather more brutal and metric driven world. Viewed through the narrow gaze of metrics the future might look difficult for all but a few top performing institutions. But there is also a very positive future in emphasising the distinctive qualities offered by an area of study that is so relevant to a post-industrial world. The challenge now for those involved in tourism studies is how to ensure that these distinctive aspects of tourism are developed, delivered and displayed.

\section{References}

Airey, D. (2005). Growth and Development. In D. Airey \& J. Tribe (Eds.), An International Handbook of Tourism Education (pp. 1324). Oxford: Elsevier.

Airey, D. (2008a). In search of a mature subject. Journal of Hospitality, Leisure, Sport and Tourism, 7(2), 3 .

Airey, D. (2008b). Tourism Education: life begins at 40. Teoros, 27(1), 27-32.

Airey, D. (2015). 40 Years of Tourism Studies - a remarkable story. Tourism Recreation Research, 40(1), 6-15.

Airey, D., Dredge, D., \& Gross, M. (2015). Tourism, Hospitality and Events Education in an Age of Change In D. Dredge, D. Airey \& M. Gross (Eds.), The Routledge Handbook of Tourism and Hospitality Education (pp. 3-14). London: Routledge.

Airey, D., Tribe, J., Benckendorff, P., \& Xiao, H. (2015). The Managerial Gaze: the long tail of tourism education and research. Journal of Travel Research, 54(2), 139-151. doi: $10.1177 / 0047287514522877$

Aitchison, C. (2006). The Critical and the Cultural: explaining the divergent paths of leisure studies. Leisure Studies, 25(4), 417422.

Austin, A. (2012). Challenges and Visions for Higher Education in a Complex World: commentary on Barnett and Barrie. Higher Education Research and Development, $3^{\prime}(1), 57-64$.

Barnett, R. (2004). Learning for an Unknown Future. Higher Education Research and Development, 23(3), 247-260.

Barnett, R. (2013). Imagining the University. London: Routledge.

Cooper, C. (2006). Knowledge Management and Tourism. Annals of Tourism Research, 33(1), 47-64.

Council for National Academic Awards. (1993). Review of Tourism Studies Degree Courses. London: Council for National Academic Awards.

Dredge, D., Airey, D., \& Gross, M. (Eds.). (2015). The Routledge Handbook of Tourism and Hsoptiality Education. London: Routledge.

Harvey, D. (2007). Neoliberalism as Creative Destruction. The Annals of the American Academy of Political and Social Science, 610(1), 21-44. doi: 10.1177/00027162062 96780

Medlik, S. (1965). Higher Education and Research in Western Europe. London: University of Surrey.

Meyer, J. H. F., \& Land, R. (2003). Threshold Concepts and Troublesome Knowledge - linkages to ways of thinking and practising. In C. Rust (Ed.), Improving Student Learning - ten years on. Oxford: OCSLD.

Tribe, J. (1997). The indiscipline of tourism. Annals of Tourism Research, 24 (3), 628657. 